\title{
Signaling mechanism of corporate payout policy: A case of Indian firms
}

\author{
Sadaf Anwar ${ }^{\mathrm{a}^{*}}$, Shveta Singh ${ }^{\mathrm{b}}$ and P. K. Jain ${ }^{\mathrm{c}}$ \\ ${ }^{a}$ Research scholar in Finance at the Department of Management Studies, Indian Institute of Technology Delhi (IIT Delhi), India \\ ${ }^{b}$ Associate Professor of Finance at the Department of Management Studies, Indian Institute of Technology (IIT Delhi), India \\ 'Professor of Finance at the Department of Management Studies, Indian Institute of Technology (IIT Delhi), India \\ C H R O N I C L E

\begin{abstract}
A B S T R A C T
\end{abstract}
Article history:

Received July 5, 2015

Received in revised format

August 162015

Accepted January 62016

Available online

January 112016

Keywords:

Event Study Cash Dividends

Share Repurchases

Signaling

India

\begin{abstract}
Historically, cash dividends are the most important form of payout policy; however, they have been losing popularity relative to share repurchases. This paper examines the signaling effect of the payout decisions namely, cash dividends and share repurchases by BSE 500 index companies. It attempts to uncover the underlying forces behind the firm's choices of payout policy in the Indian context. Using the standard 'Event Standard Methodology', a strong case of positive signaling is reported in case of repurchase announcements vis-a-vis cash dividend announcements. It is observed that cash dividends are not perceived by investors as positive signals as they prefer their earnings to be retained by the companies for growth prospects. In case of share repurchases, the existence of undervaluation, signaling and wealth transfer hypotheses is reported, consistent with the fact the share repurchases are welcomed by the Indian companies. The results would provide insights into the economics of the choice between cash dividends versus share repurchases as payout mechanism adopted by the sample companies. The findings would also be useful to the academia as well as industry in understanding the payout practice and the extent to which the Indian managers use the assumptions, models and decision rules regarding payout.
\end{abstract}

C 2016 Growing Science Ltd. All riphts reserved.

\section{Introduction}

Corporate payout decisions are to be one of the strategic decisions that a financial manager has to take for the realization of the corporate goal which is the maximization of the value of the shareholders. Shareholder distribution is an area of intense scrutiny. Even though, the empirical literature has focused on dividend as the most common type of payout; dividend payments still remain a controversial topic in literature (Black, 1976). An alternative for dividend payment is the share repurchases decision. Dividends and share repurchases are the principal mechanisms by which corporates disburse cash to their shareholders. Several studies have analyzed the responses of share prices to the announcements of these modes of cash distribution.

* Corresponding author.

E-mail address: sadafanwar25@gmail.com (S. Anwar) 
The stock market has witnessed a gradual increase in dividend and share repurchase announcements due to languishing share prices and uncertain futures. Companies lacking sufficient growth prospects to earn returns above their weighted average cost of capital can best serve shareholders with cash distributions - either dividends or share repurchases. In fact, significant 'announcement effects' have been reported by firms on the occurrence of such events. Literature has emphasized on signaling hypotheses as the two major theories for explaining the market reaction to cash disbursement (Liljeblom \& Pasternack, 2006; Sedzro, 2010). According to the signaling hypothesis there exists an informational asymmetry about the firm's future prospects between the mangers and shareholders. The firm's management is better informed about the company's true value than the outside shareholders. Therefore, cash dividends and share repurchases announcements convey positive signals about the firm's future earnings prospects. They signal to the investors that managers are confident about the company's future (Aharony \& Swary, 1980; Wansley et al., 1989; Grullon \& Ikenberry, 2000; Baker et al., 2003).

It is also worth mentioning that most of the literature in the Indian context has analyzed either the dividend or the share repurchases decision. Since, both these decisions are consequences of the payout decision, this paper has made an attempt to analyze the market reaction to cash dividend and share repurchase announcements both exclusively and in combination with each other. Thus, the firms' decision to distribute cash flows and their choices between paying out cash flows in the form of dividends or stock repurchases has been examined on the sample of BSE 500 index firms listed on the Bombay Stock Exchange (BSE).

For better exposition, this paper is divided into seven sections: Section one contains the introduction. Section two contains the pertinent literature. Section three presents gaps found in the literature. Section four contains the objectives and the hypotheses. Section five discusses the methodology, scope and the rationale of the study. Section six presents and analyses the results. Section seven contains the concluding observations and implications.

\section{Literature Review}

\subsection{Interrelationship between dividends and share repurchases}

The emergence of repurchases as an economically significant phenomenon has generated a vigorous debate in literature with regard to whether dividends and repurchases are substitutes or whether they represent two distinct forms of payout mechanisms, adopted by different types of firms at different stages of their life-cycle. This section provides insight into the economics of the choice between dividends versus repurchases.

For instance, 'substitution hypothesis' is based on the increasing propensity of repurchases and a declining trend in paying dividends. It assumes that the share repurchases and dividends are substitute payout methods (Grullon \& Michaely, 2002; Skinner, 2008; Eije \& Megginson, 2008; Kooli \& L'Her, 2010). Either dividends or share repurchases can be used to signal the undervaluation of a firm or to avoid agency costs (Gurgul \& Majdosz, 2005). According to Miller and Rock (1985), dividends and repurchases are perfect substitutes and either announcement elicited the same market reaction. The results were consistent with the undervaluation and the free cash flow hypotheses.

Differing from the above notion, John and Williams (1985) concluded that dividends and share repurchases were not perfect substitutes since dividends were taxed at a higher rate than revenues from repurchases. Thus, the market should be different in the two cases. In a study by Ofer and Thakor (1987), dividend and repurchase decisions were viewed as valid signals. Similar conclusions were laid down by various studies by Brennan and Thakor (1990); Choi and Chan (1997); Choi and Chen (1997); Lee and Rui (2007); Ming et al. (2008). 
From another perspective, literature cites 'financial flexibility' inherent in repurchase programs as the reason for their practice over payment of dividends (Baba \& Ueno, 2008). Research findings have mentioned the situations and the factors where each of them might be suited to firms in different stages of their life cycles. Managers use dividends to pay out permanent cash flows, while repurchases are used to pay out temporary cash flows relatively quickly and therefore represent two distinct forms of payout utilized by firms in fundamentally different circumstances (Jagannathan et al., 2000; Dittmar \& Dittmar, 2002). Further, several authors have concluded that while factors such as stock price performance, excess cash on the balance sheet, and dilutive effects of options drive repurchases, life cycle factors such as profitability, maturity, size, leverage, and reduced investment opportunities tend to favor dividends (Brav et al., 2005; Grullon \& Michaely, 2002; Skinner, 2008; Coulton \& Ruddock, 2011). Dividends are generally visualized as positive signals from the management and both the companies and shareholders prefer a stable dividend policy. It is only when the company has extraordinary excess earnings that it prefers share repurchases. Thus, the company and the stakeholders can avoid expectations that this extraordinary payment will be regularly repeated (Gurgul \& Majdosz, 2005).

Generally, the discussion of the choice between the two revolves around Black's (1976) proposition of repurchases' tax advantage relative to dividends. As such, this research focused on examining the economic consequences of the choice between dividends versus repurchases is likely to be a useful area of inquiry in Indian stock market.

\subsection{The Choice between Dividends and Share Repurchases}

Numerous studies have examined whether payout increases or decreases convey favorable (unfavorable) information about future cash flow as found by signaling models (Bhattacharya, 1979; Miller \& Rock, 1985). In sum, the results suggest that firms that increase their payout either through dividends or share repurchase experience an increase in their future operating performance and viceversa. However, this evidence is mixed and inconclusive (Lie, 2005).

Few studies have examined the choice between repurchases and dividends. This section delineates some of the common factors that drives the choice between the two and the information (if any), investors infer from this managerial choice.

Literature has illustrious history behind the corporate choice between cash dividends and share repurchases. There were obvious advantages accruing to paying dividends if we go back over a century or more. Any firm consistently adhering to dividend payment was believed to signal future earning potential. On the other hand, firms that constantly repurchased shares were being suspected with manipulating the stock prices Moreover, share repurchase by individuals was considered to be an expensive business due to direct transaction costs involved. Also there were increased instances of insider trading being reported on account of such actions by the firms. This environment established a convention that paying dividends was good and cutting dividends was bad.

However, repurchases are now being employed by firms without risk and have become an acceptable alternative. Such a change is fueled by changes in regulation, tax laws and attitudes towards shareholder value maximization as the ultimate corporate goal. The reduction in dividends is perceived as a bad signal (at least in the short run), firms are not willing to replace dividends with repurchases even though repurchases have tax advantages. However, as payout is increased, repurchases can be increasingly used.

The other piece of the payout puzzle is that total payout yield in terms of dividends and repurchases has remained fairly constant at least for the last ten years. One possible explanation for this is a signaling story. The market treats increases in dividends and repurchases as good news. In theory, this reaction could be because increases are interpreted as signals of future operating performance. However, there 
is evidence that increases in payout are not followed by improved operating performance, thus rejecting this explanation. An alternative interpretation is that the market is relieved that managers will no longer acquire cash that can be squandered, and this is why an increase in payout leads to a higher share price.

Dividends have been considered as the more preferred alternative while the open market repurchases the most costly choice by the firms in a study by Barclay and Smith (1988). Similarly, a recent study by Jong et al. (2003) also supported the view point that dividends were the best choice for optimal payout policy. Similar results were drawn by Chowdhry and Nanda (1994) where undervaluation was observed as the reason for firms engaged in a stock repurchase program. Dividend decisions were driven by life cycle and catering theory considerations, while signaling theory provides a better explanation for payout through share repurchases (Jain et al., 2009).

Differing from the viewpoint supporting dividends to be the best optimal payout policy, Allen and Michaely (2002) and Weigand and Baker (2009) concluded repurchases as a dominant form of payout as compared to dividends. The benefits of personal tax considerations were associated more with share repurchases than with dividends (Hsieh \& Wang, 2008; Grullon et al., 2011). Also Bartov et al. (1998) concluded that managers choose repurchase over dividend if management views its shares as greatly undervalued. Denis (1990) study indicated dividend payments as instruments to increase the wealth of target firm shareholders relative to repurchases. With a different view, Brennan and Thakor (1990) developed a theory of choice and found that small distribution firms' preferred dividends while for large distributions firms' favored share repurchases. Further, Hausch and Seward (1993) concluded dividends as deterministic disbursement while share repurchases to be stochastic disbursement of payout decisions.

Researchers have also cited cash flow permanence as an important factor when going for the choice between dividends and repurchases (Guay \& Harford, 2000). Jagannathan et al. (2000) observed that the performance was better for firms that increased regular dividends than for firms that repurchase shares. Also Hsieh \& Wang (2008) results suggested that the firms with greater insider ownership preferred share repurchases to cash dividends. Repurchases were efficient for erasing larger stock undervaluation whereas dividends would be chosen for mitigating agency problem (Sedzro, 2009). Also dividends were considered as instruments to provide immediate cash to shareholders, but share repurchases produced a greater opportunity for capital appreciation.

The study by DeAngelo and DeAngelo (2006) proposed a lifecycle explanation of dividends whereby younger firms with high growth opportunities will refrain from paying dividends while more mature firms with large cash flows and less investment opportunities will optimally pay out the excess funds. These findings were complementary with the findings of Sedzro (2010) where undervalued firms preferred share repurchase while firms with growth opportunities preferred using special dividends. Further, Douglas (2007) inferred that repurchases provide an opportunity to increase wealth of the managers relative to dividends. Mangers were more inclined in share repurchases for short run growth of stock prices and shareholder value instead of dividend payments (Nippel \& Nekat, 2009).

A study of preference among individual and institutional investors by Jain (2007) concluded that informationally superior institutional investors preferred firms that engage in larger share repurchases whereas individual investors did not preferred share repurchases. Thus, the investment horizons might be one contributing factor to the increasing popularity of buybacks (Gaspar et al. 2012). Also stock repurchases were effective in countries with strong investor protection than dividends (Haw et al., 2011).

In terms of market reactions to share repurchase and cash dividend announcements, researchers have different views. Stock price reactions elicited a more positive response in case of share repurchases than dividends (Choi \& Chen, 1997; Chhachhi \& Davidson; 1997; Lie, 2000). Whereas Guay \& 
Harford (2000) results found a higher positive market response to dividend increases when compared to open market repurchases. Few studies have also concluded that dividends and repurchases both substitute and complement each other (e.g. see Dittmar \& Dittmar, 2002). However Allen and Michaely (2002) reported that both cash dividends and share repurchases have similar effects in terms of impact. The only difference they observed was that repurchases were larger in size relative to dividends.

Thus, according to the literature cited, it seems that researchers do not possess strong evidence regarding the announcement of either method conveying positive information about the value of the firm (Allen \& Michaely, 2002). There appears to be no definite clarity on what motivates the decision to pay cash in the form of dividends or share repurchases. Thus, empirical evidences continue to question the role of dividends and share repurchases as signals of value maximization and better performance.

This paper attempts to contribute to the understanding of payout behavior of Indian firms with respect to both dividends and share repurchase announcements.

\section{Gaps in Literature}

Corporates use dividends and share repurchases as the two main methods to distribute cash to shareholders. While each method has received considerable attention in the academic literature, only few studies have examined the choice between repurchases and dividends in the Indian context. The study by Thirumalvalavan \& Sunitha (2006) is the only India study (to the best of authors' knowledge) where instances of strong signaling power of stock repurchases announcements as compared to dividend announcements was reported. In particular, the factors that drive the choice between dividends and repurchases and what, if any, information investors infer from this managerial choice are largely unreported. Since, share repurchase is a recent phenomenon in India as compared to US and other European countries; the paper would help in understanding the payout behavior of Indian firms and psychology of the investors towards announcements of such events. Thus, to the best of the authors' knowledge, this study attempts to fill this research gap.

\section{Objectives and Research Hypotheses}

The purpose of the paper is to examine and compare the market reaction to announcements of cash dividends and share repurchases; it also tests the existence of signaling impact among Indian companies. Further, it investigates the reasons why firms might choose one payout form over another.

The following hypotheses have been formulated:

$\mathrm{H}_{1}$ : There is no positive signaling in share price behavior around cash dividend announcements.

$\mathrm{H}_{2}$ : There is no positive signaling in share price behavior around share repurchase announcement.

\section{Research Methodology}

\subsection{Event Study Methodology}

The event study methodology (Brown \& Warner,1985) has been employed to estimate abnormal returns and test statistics for testing the signaling impact of cash dividends and share repurchases announcements on abnormal as employed by Thirumalvalavan and Sunitha (2006).

Following the seminal articles by Ball and Brown (1968) and Fama et al. (1969) event studies have become one of the widely used empirical techniques to detect abnormal price changes in financial assets in the time period around various events. Event methodology enables to assess if there are any abnormal returns earned by the investors due to these events. An event study procedure (Brown and Warner, 
1985), therefore, can be used to measure changes in share value around the dividend reduction or omission announcements. Bowman (1983) identified the following 5 steps in conducting an event study:

1. Identify the event of interest.

2. Model the security price reaction.

3. Estimate the excess returns.

4. Organize and group the excess returns.

5. Analyze the results.

This methodology has proved to be very useful in a variety of finance related fields such as corporate finance, accounting, management, etc. Examples are studies of the impact of mergers and acquisitions, stock splits, new legislations, earning announcements, and other finance related events, on the profitability of firms.

A vast literature on the theory of event study methods also exists (Bowman, 1983; Brown \& Warner, 1985). To determine an appropriate event window for this study, the different models used in an event study was referenced to determine the most appropriate event window. An event window that is too short may undermine the predictive power of the forecasting model while an event window that is too long may produce an unstable model due to structural variations occurring within the period. Hence, an event window examined is 31 days i.e. 15 days prior to the announcement date (AD-15) to 15 days after the announcement date $(\mathrm{AD}+15)$ along with the announcement day itself (Wann et al., 2008). The announcement day (AD) is denoted as day zero (when cash dividend and share repurchase is announced for the first time in the public newspapers). The estimation period for the market model parameters (value weighted market index, BSE 500 index) is 150 days prior to the announcement day. Fig. 1 depicts the event window and estimation window.

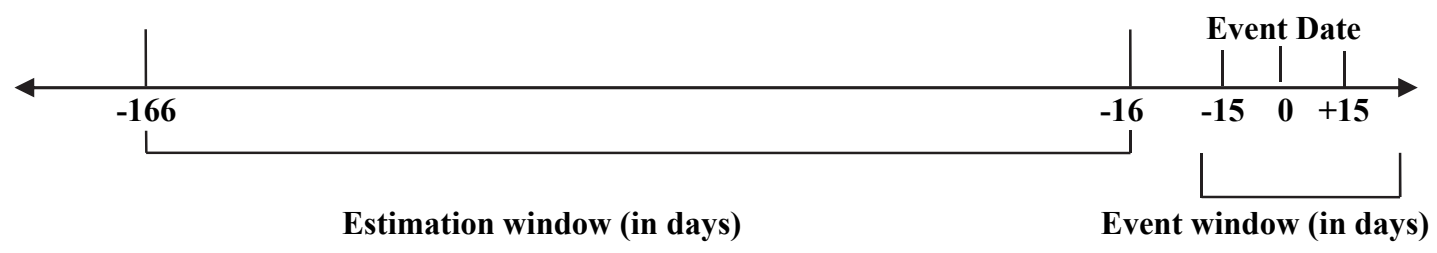

Fig. 1. Time line for Event Study (in days)

The traditional market model to estimate abnormal returns as per the Eq. (1):

$$
\mathrm{R}_{i, t}=\alpha_{i}+\beta_{i} \mathrm{R}_{m, t}+\mathrm{E}_{i, t}
$$

The abnormal return (AR) for each day for each firm is then obtained as per the Eq. (2):

$$
\mathrm{AR}_{i, t}=\mathrm{R}_{i, t}-\left(\alpha_{i}+\beta_{i} \mathrm{R}_{m, t}\right) \text {, }
$$

where $\alpha$ and $\beta$ are the estimated parameters, $\mathrm{R}_{i, t}$ is the expected return on stock $i$ at time $t, \mathrm{R}_{m, t}$ is the corresponding return on the BSE 500 index and $\mathrm{E}_{\mathrm{i}, \mathrm{t}}$ is the error term. 'Abnormal return' is the difference between the daily return and expected return on a particular day. The abnormal return for all the firms on each day of the event is then aggregated and averaged to obtain the average abnormal return (AAR). To ascertain the accumulated impact of the event during a particular time period, cumulative average abnormal returns (CAAR) are computed. The test statistic for AAR on day $t$ during the event period and for CAAR for the event window $\left(t_{1}, t_{2}\right)$ is given by the Equations 3 and 4 respectively:

$$
\text { t-statistic }=A A R / \sigma\left(A A R_{t}\right),
$$


$t$-statistic $=C A A R t /\left(t_{2}-t_{1}+1\right) 1 / 2 \sigma\left(A A R_{t}\right)$

5.2 Scope and Data collection

The scope of the paper is limited to BSE 500 index companies. The BSE 500 index of the Bombay stock exchange (BSE) comprises of the top 500 companies listed with the Bombay Stock Exchange, based on their market capitalization. The BSE 500 index of the Bombay stock exchange (BSE) comprises of the top 500 companies listed with the Bombay Stock Exchange, based on their market capitalization. It represents nearly 93 per cent of the total market capitalization on BSE and covers 20 dominant sectors of the economy (as on 7 November 2012, the date of sample selection).

The present study chooses India as it is one of top five countries representing the emerging markets. In recent years, the Indian stock has become an active hub of activity where expansion and a faster more inclusive economic growth strategy are encouraged. Both the firms and shareholders are experiencing improvements in financial ratios better earnings prospects and shareholder value is created. The regulatory framework has induced an environment for companies to conduct financial transactions by providing a financial link between issuers, analysts and investors. In countries where the stock markets are recently developed, the motivation for managers to use dividends and repurchases as a signaling mechanism may be stronger in such an environment. A test of the signaling theory in India could shed light on the evidence on the market reaction to earnings announcements and distribution policy changes. Due to the limited availability of studies in this area, this study will add to the finance literature.

The cash dividend and share repurchase announcements for the period of 5 years $\left(1^{\text {st }}\right.$ April 2008 to $31^{\text {st }}$ March 2013) were collected from Prowess ${ }^{\circledR}$ and the Capitaline ${ }^{\circledR}$ database, websites of Moneycontrol, Economic Times, BSE and SEBI. The data has been analyzed using the Statistical Package for Social Sciences $\left(\right.$ SPSS $\left.^{\circledR}\right)$ and Microsoft's Excel ${ }^{\circledR}$ worksheet.

\subsection{Sample Selection Criteria}

Table 1 provides the selection summary. To ensure that the event window was not contaminated with any other type of announcement; only 'pure' cash dividends and share repurchase announcements have been considered. Hence, the announcements like stock dividends and stock splits, bonus issue and share repurchase mergers, acquisitions, amalgamation, joint venture, capital investment, substantial orders from prestigious customers or any other such financial events during the event window will not considered as a part of the sample (McWilliams \& Seigel, 1997). The reason for the sample selection criteria is to ensure that the returns accruing to the firms on announcement of these events are not influenced by any other corporate actions. The considered announcements (after applying the sample criteria) for cash dividends are 207 and for share repurchases 33 announcements.

Table 1

Sample Selection Summary

\begin{tabular}{lcc}
\hline & Cash Dividends & Share Repurchases \\
\hline Population & 500 & 500 \\
Less: & & 78 \\
Finance companies & 78 & 378 \\
Data not available & 48 & 19 \\
Companies not adhering to sample criteria & 223 & 27 \\
Sample & 151 & \\
\hline
\end{tabular}

\section{Empirical results}

Table 2 depicts that the presence of negative abnormal returns on the announcement day ( 0.23 per cent) and also on days before and after the announcement; this implies that the cash dividend announcements do not create a positive effect among the investors. The AARs during the event window have been observed to be statistically insignificant. An AAR of 0.21 is realized on the second day after the 
announcement and thereafter the return continues to decelerate. The highest AAR is 0.35 per cent in the post announcement period $(\mathrm{AD}+6)$ and 0.45 per cent in the pre announcement period (AD-9). It is also observed that the abnormal returns are positive on AD-5, AD-4 and AD-3 days in the preannouncement event window. Further, a positive AAR is observed on $\mathrm{AD}+5$ to $\mathrm{AD}+6$ days subsequently followed by a significant decline. The CAAR is also negative during the window period, except on $\mathrm{AD}+6$ day ( 0.20 per cent). The results are however found to be significant only on $\mathrm{AD}+9$ day after the announcement of cash dividend. The highest positive abnormal returns aggregate to only 0.20 per cent both in the pre-announcement and post- announcement period.

\section{Table 2}

Average Abnormal Returns (AARs) and Cumulative Average Abnormal Return (CAARs) and their corresponding t-statistic values on and around Cash Dividend and Share Repurchase Announcements

\begin{tabular}{|c|c|c|c|c|c|c|c|c|}
\hline \multicolumn{5}{|c|}{ Cash Dividends } & \multicolumn{4}{|c|}{ Share Repurchases } \\
\hline Davs & $(\mathrm{AAR})(\%)$ & $\mathrm{t}$-statistic & CAAR $(\%)$ & t-statistic & $(\mathrm{AAR})(\%)$ & $\mathrm{t}$-statistic & CAAR $\%$ & $\mathrm{t}$-statistic \\
\hline-15 & -0.31 & -0.9237 & -0.31 & -0.1659 & 0.23 & 0.3551 & 0.23 & 0.0638 \\
\hline-14 & -0.20 & -0.5828 & -0.51 & -0.2706 & 0.89 & 1.3519 & 1.12 & 0.3066 \\
\hline-13 & -0.20 & -0.6004 & -0.72 & -0.3784 & -0.22 & -0.3348 & 0.90 & 0.2465 \\
\hline-12 & 0.02 & 0.0487 & -0.70 & -0.3697 & -0.13 & -0.1943 & 0.77 & 0.2115 \\
\hline-11 & -0.17 & -0.5038 & -0.87 & -0.4602 & 0.80 & 1.2212 & 1.58 & 0.4309 \\
\hline-10 & 0.45 & 1.3172 & -0.42 & -0.2236 & -0.34 & -0.5216 & 1.23 & 0.3372 \\
\hline-9 & -0.09 & -0.2553 & -0.51 & -0.2694 & 1.07 & 1.6337 & 2.31 & 0.6306 \\
\hline-8 & 0.41 & 1.2024 & -0.10 & -0.0535 & -0.57 & -0.8638 & 1.74 & 0.4755 \\
\hline-7 & -0.36 & -1.0475 & -0.46 & -0.2416 & -0.17 & -0.2517 & 1.57 & 0.4303 \\
\hline-6 & -0.10 & -0.2852 & -0.55 & -0.2928 & 0.29 & 0.4426 & 1.86 & 0.5098 \\
\hline-5 & 0.11 & 0.3208 & -0.44 & -0.2352 & 0.63 & 0.9553 & 2.49 & 0.6813 \\
\hline-4 & 0.59 & 1.7289 & 0.14 & 0.0753 & 0.57 & 0.8613 & 3.06 & 0.8360 \\
\hline-3 & 0.06 & 0.1775 & 0.20 & 0.1072 & 0.68 & 1.0331 & 3.74 & 1.0216 \\
\hline-2 & -0.20 & -0.5998 & 0.00 & -0.0005 & 0.94 & 1.4327 & 4.68 & 1.2789 \\
\hline-1 & -0.03 & -0.0752 & -0.03 & -0.0140 & 0.41 & 0.6176 & 5.08 & 1.3898 \\
\hline 0 & -0.23 & -0.6780 & -0.26 & -0.1358 & 0.42 & 0.6435 & 5.51 & 1.5054 \\
\hline 1 & -0.04 & -0.1222 & -0.30 & -0.1577 & -0.62 & -0.9453 & 4.88 & 1.3356 \\
\hline 2 & 0.21 & 0.6176 & -0.09 & -0.0468 & -0.39 & -0.5950 & 4.49 & 1.2288 \\
\hline 3 & -0.12 & -0.3625 & -0.21 & -0.1119 & 0.15 & 0.2232 & 4.64 & 1.2688 \\
\hline 4 & -0.02 & -0.0466 & -0.23 & -0.1203 & 0.50 & 0.7630 & 5.14 & 1.4059 \\
\hline 5 & 0.08 & 0.2445 & -0.14 & -0.0764 & 0.27 & 0.4146 & 5.41 & 1.4803 \\
\hline 6 & 0.35 & 1.0231 & 0.20 & 0.1074 & 0.12 & 0.1858 & 5.54 & 1.5137 \\
\hline 7 & -0.41 & -1.2174 & -0.21 & -0.1113 & -0.26 & -0.3956 & 5.28 & 1.4427 \\
\hline 8 & -0.28 & -0.8376 & -0.50 & -0.2617 & 0.26 & 0.4018 & 5.54 & 1.5149 \\
\hline 9 & -0.96 & $-2.8268 *$ & -1.46 & -0.7694 & 0.21 & 0.3219 & 5.75 & 1.5727 \\
\hline 10 & -0.37 & -1.1002 & -1.83 & -0.9670 & 0.23 & 0.3516 & 5.98 & 1.6358 \\
\hline 11 & -0.14 & -0.4064 & -1.97 & -1.0400 & 0.13 & 0.1940 & 6.11 & 1.6707 \\
\hline 12 & -0.21 & -0.6147 & -2.18 & -1.1504 & -0.39 & -0.5997 & 5.72 & 1.5629 \\
\hline 13 & -0.01 & -0.0339 & -2.19 & -1.1565 & 0.98 & 1.4937 & 6.70 & 1.8312 \\
\hline 14 & -0.06 & -0.1724 & -2.25 & -1.1875 & 0.58 & 0.8896 & 7.28 & 1.9910 \\
\hline 15 & -0.17 & -0.4955 & -2.41 & -1.2765 & -0.41 & -0.6284 & 6.87 & 1.8781 \\
\hline
\end{tabular}

\subsection{Analysis of Cash Dividend Announcements}

In the context of signaling, it may be concluded that cash dividends are not perceived by investors as a positive signal and they prefer their earnings to be retained by the companies rather than paying them as dividends. It appears that investors assign more credence to the information content of negative dividend signals in comparison to positive dividend signals. These findings complement that of Rimbey and Officer (1992), Koch and Sun (2004), Kadioglu (2008) Asamoah and Nkrumah (2010). The insignificant impact on the returns could also be due to the presence of insider trading (Ali \& Chowdhury (2010). There might also be a possibility that the sample firms have entered the decline stage of their life-cycle where they have less investment opportunities as supported by the Maturity Hypothesis (Fracassi, 2008). Figures II and III depict the trend of abnormal returns.

In sum, there is not much evidence to vouch for the fact that cash dividend announcements signal the bright future earnings prospects of the sample companies. The signaling hypothesis has been losing ground, as more recent research vouch for the fact that cash dividend announcements are not very good 
predictors of future earnings growth of the sample companies (DeAngelo et al., 1996; Benartzi et al., 1997). Also Brave et al. (2005) found that managers do not have signaling purpose in their mind when they decide on payout policy.

According to the results, the hypothesis $\mathrm{H}_{1}$, which states that there is no positive signaling around cash dividend announcements is accepted.

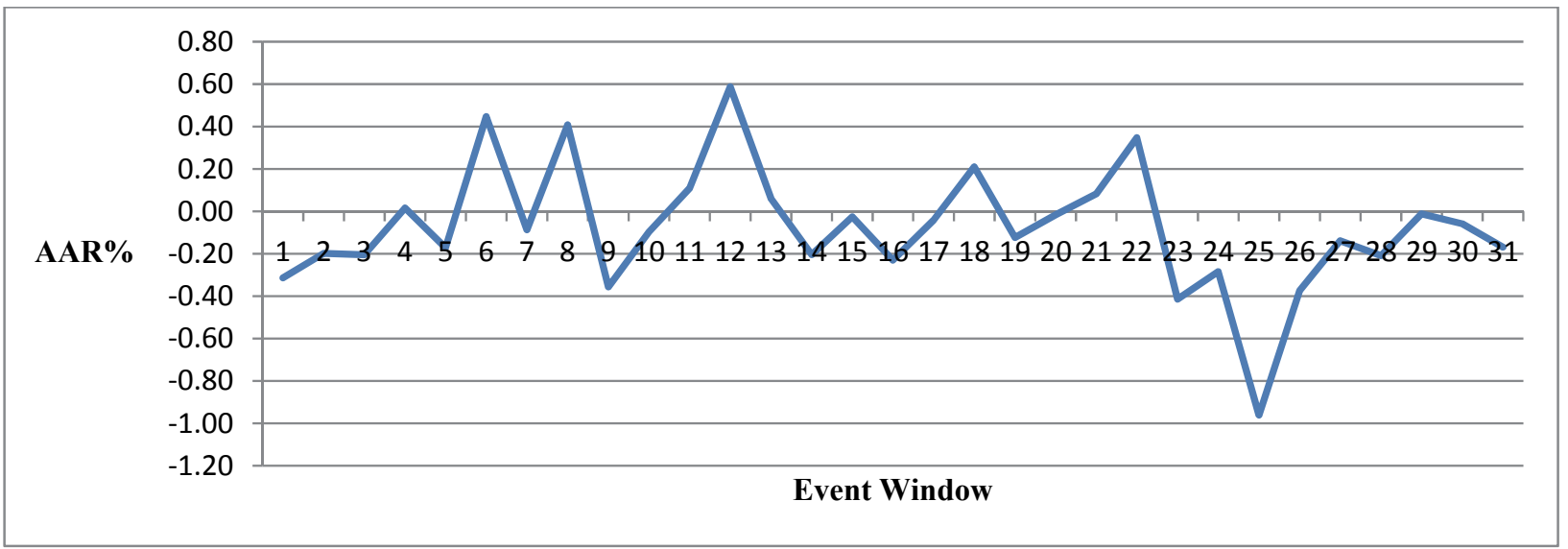

Fig. 2. AARs for Cash Dividend Announcements

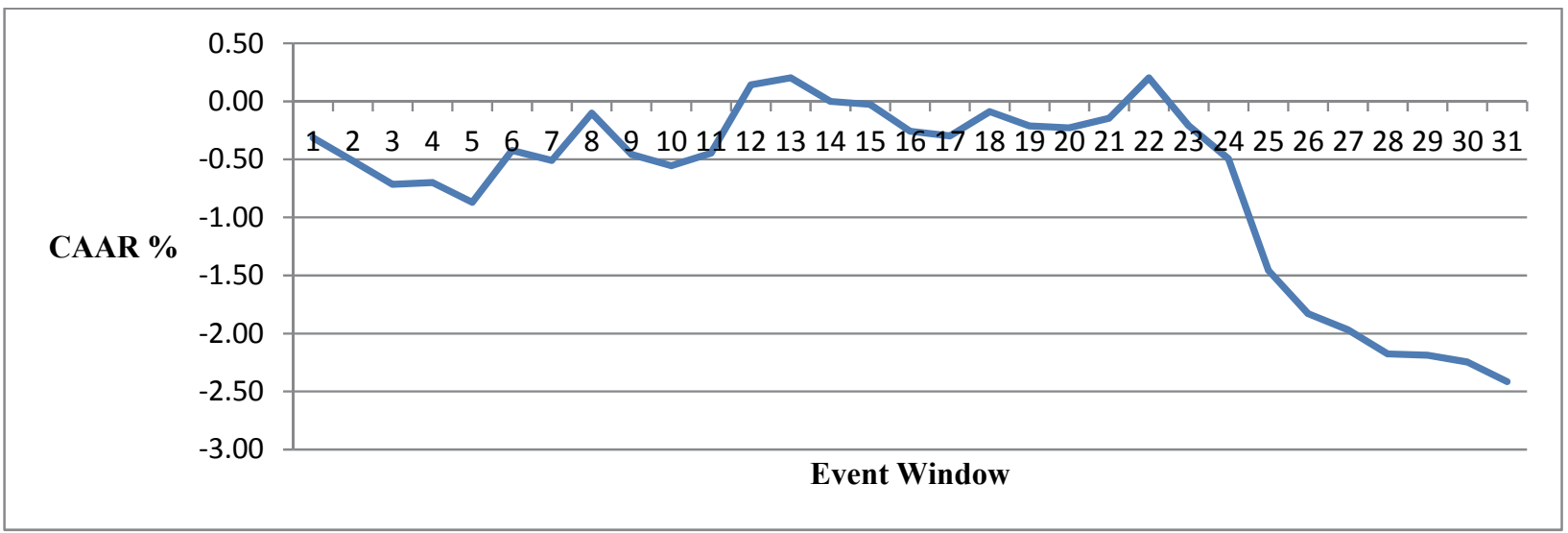

Fig. 3. CAAR for Cash Dividend Announcements

\subsection{Analysis of Share Repurchase Announcements}

The results documented in Table 2 supports the existence of undervaluation, signaling and wealth transfer hypotheses in the Indian stock market (Bartov et al., 1998; Commment \& Jarrel, 1991; Gyrgul \& Majdosz, 2005; Sedzro, 2009). The sample companies perhaps believe that the share repurchase will help them achieve superior performance and returns for the shareholders. The average abnormal return (AAR) of 0.42 per cent is observed on the announcement day and cumulative average abnormal return (CAAR) of 6.87 per cent can be observed for sample companies. The CAARs are positive during the 31 days of the event window. Having recorded positive average abnormal returns from AD- 1 to AD-6 in the pre-event window, the post event abnormal returns get are negative for two days (AD +1 to $\mathrm{AD}+2$ ), thereby evidencing the mixed nature of abnormal return booking. Figures IV and V depict the trend of abnormal returns. It can be inferred that the share repurchase announcements have information content to effect a change in prices leading to positive AARs, for a shorter period of time. The prices adjust to the new information quickly, thereby, offering no opportunity to book abnormal profits on a sustained basis. However, it is surprising to notice the positive AARs during the pre-event days from AD-6 to AD-1; perhaps an indication of in insider trading (Li \& McNally, 2007). Also, it appears that 
the market does not given any scope for earning abnormal returns on a sustained basis. This aspect favors the semi-strong form of efficiency in the Indian stock market (Dua et al., 2010). These findings are also in tune with the survey evidence by Wansley et al. (1989). The existence of negative abnormal returns just post announcement may be an indication that the share repurchases does not lead to an improvement in the valuation of shares. The motive here appears to increase in promoters' stake using the funds which belong to the company (Mishra, 2005). The findings also suggest that by trading their own stock, companies can successfully reduce short-term price instability, thereby smoothening price discovery and lending credence to 'price support hypothesis' (Cesari et al., 2011). Besides undervaluation, the repurchasing decisions of Indian firms may be attributed to excess cash flows. It also signifies that the firms' repurchasing shares are in their mature stage of their life cycle to dispense excess free cash flow (Liang et al, 2011). The results also provide some support for leverage adjustment hypothesis because repurchasing firms use less debt compared to non-repurchasing firms (Medury et al., 1992).

According to the results, the hypothesis $\mathrm{H}_{2}$, which states that there is no positive signaling around share repurchases announcement is rejected.

The above findings are consistent with earlier studies in other markets suggesting that open market share buybacks are welcomed by the markets (Comment \& Jarrell, 1991; McNally, 1999; Baker et al., 2003; Li \& McNally, 2003). The Indian stock market reaction to the buyback announcements is not different from the reaction of western studies as it signals the undervaluation of shares. While share repurchases can be an effective restructuring strategy of a company, its effects are short-term. They can be construed as a strategy/tactic that enables management to realign their business and should not be viewed as a replacement or substitution strategy (Dixon et al., 2008). The more mangers are concerned for short run growth of stock prices and shareholder value, the more they might be interested in repurchases instead of dividend payments.

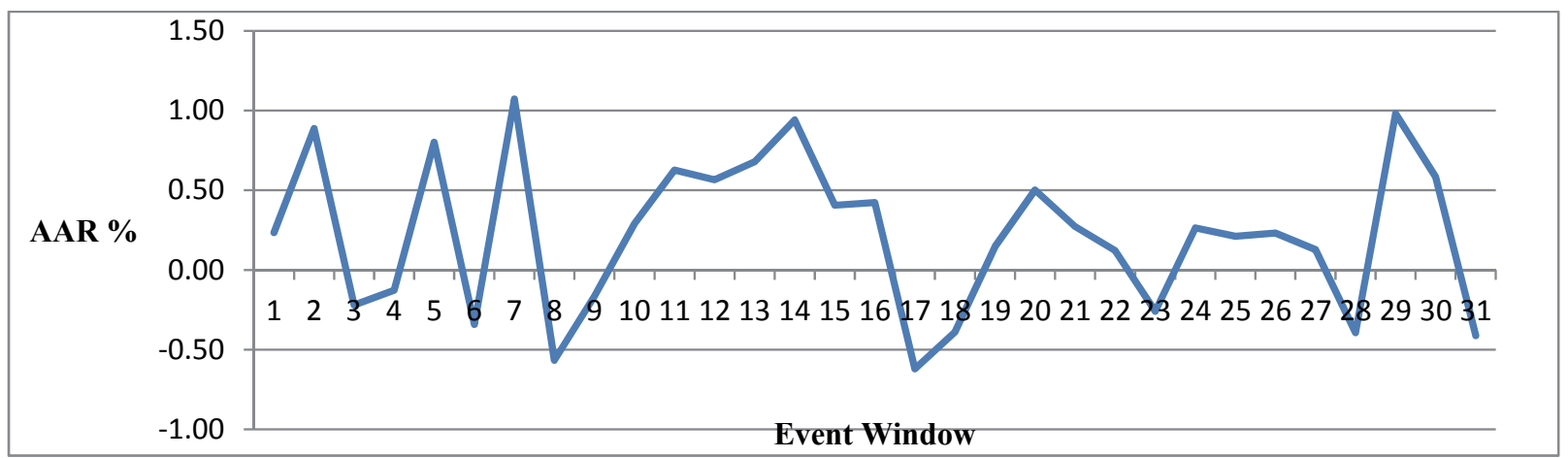

Fig. 4. AARs for Share Repurchase Announcements

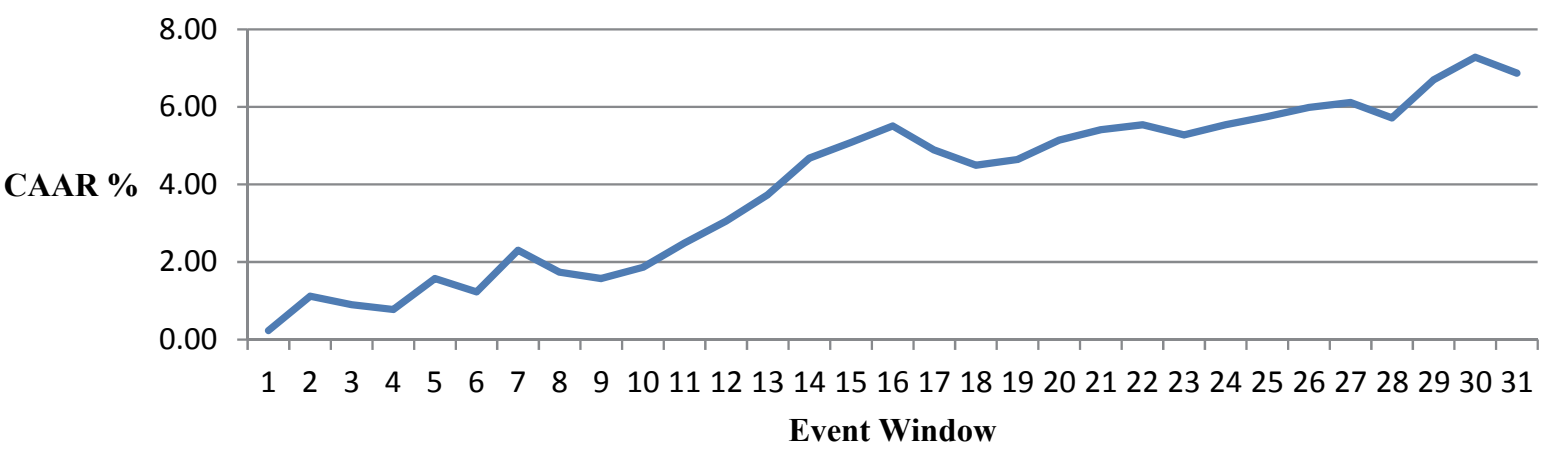


Fig. 5. CAARs for Share Repurchase Announcements

It is evident from the results that the impact of cash dividend and share repurchase announcements does not seem to sustain for a very long time in Indian context. The changing market environment in terms of more sophisticated investors, lower trading cost, better liquidity, and more transparent and credible information disclosure do not allow investors to earn abnormal return consistently. Moreover, the enactment of the Sarbanes-Oxley Act in 2002 has strengthened corporate governance and disclosure information by the firms. Further, evidence suggests that recent events are conducted more for business operating reasons than for market timing. Thus, both the external market environment and the internal firm factors contribute to the disappearance of abnormal returns following these two events as reported by Kong and Huang (2014). The disappearance is consistent with an improvement in pricing efficiency of event stocks. Compared with event stocks in the early period, recent event stocks are held and traded more by institutions and hedge funds, are followed by more financial analysts (i.e., more transparent in information), and are more liquid and less costly to trade. In addition to these external market factors, internal firm factors also contribute to the disappearance of abnormal returns. Due to enhanced regulations, recent event firms refrain from manipulating earnings and information disclosure to mislead investors. Recent events are less motivated for the purpose of market-timing; instead, they seem motivated more for business operating reasons.

\section{Concluding Observations and Implications}

The paper has made an attempt to analyze and compare the effect of cash dividends and share repurchases announcements on the Indian capital market. The findings extend and support the results of the earlier studies. The main findings are listed below:

7.1 In the context of cash dividends, it can be inferred that the signaling hypothesis has been losing ground, as more recent research vouch for the fact that cash dividend announcements are not very good predictors of future earnings growth of the sample companies (DeAngelo et al., 1996; Benartzi et al., 1997). Also the survey evidences by Brave et al. (2005) found that managers do not have signaling purpose in their mind when they decide on payout policy. These findings complement that of Rimbey and Officer (1992), Koch and Sun (2004), Kadioglu (2008) Asamoah and Nkrumah (2010).

7.2. There might also be a possibility that the sample firms have entered the decline stage of their lifecycle where they have less investment opportunities as supported by the Maturity Hypothesis in the context of cash dividends (Fracassi, 2008).

7.3. The signaling and the information content impact is found to be more prevalent on repurchase announcements as compared to cash dividend announcements (Bartov et al., 1998; Commment \& Jarrel, 1991; Gyrgul \& Majdosz, 2005; Sedzro, 2009). Share repurchase announcements are perceived as 'good news' and anticipated by the market well in advance as evident from the positive AARs before the announcement as well as increasing CAARs after the announcement.

7.4. The prices adjust to the new information quickly, thereby, offering no opportunity to book abnormal profits on a sustained basis; it perhaps signifies an indication of in insider trading (Li and McNally, 2007). This aspect further favors the semi-strong form of efficiency in the Indian stock market (Dua et al. (2010) and lend credence to 'price support hypothesis' (Cesari et al., 2011).These findings also confirm with the survey evidences by Wansley et al. (1989), signifying managers' confidence in the firms with respect to share repurchase announcements.

7.5. The repurchasing decisions of Indian firms may be attributed to excess cash flows. It also signifies that the firms' repurchasing shares are in their mature stage of their life cycle to dispense excess free cash flow (Liang et al., 2011).

7.6. Share repurchases can be construed as a strategy/tactic that enables management to realign their business and should not be viewed as a replacement or substitution strategy (Dixon et al., 2008). The findings would help in providing the economic rationale behind the payout form chosen. Also, they 
would provide additional insights into the economics of the choice between dividends versus repurchases as the form of payout initiation mechanism adopted by the sample companies. The results might be of immense use to academia and the industry to understand the payout practice and develop new theories.

\section{References}

Aharony, J. \& Swary, I. (1980) Quarterly dividend and earnings announcements and stockholders' returns: an empirical analysis. The Journal of Finance, 35(1), 1-12.

Allen, F. \& Michaely, R. (2002). Payout policy. Working paper. The Wharton Financial Institutions Center, 1-150.

Ali, M.B. \& Chowdhury, T.A. (2010). Effect of dividend on stock price in emerging stock market: a study on the listed private commercial banks in DSE. International Journal of Economics and Finance, 2(4), 52-64.

Asamoah, G.N. \& Nkrumah, K. (2010). The impact of dividend announcement on share price behavior in Ghana. Journal of Business \& Economics Research, 8(4), 47-58.

Baba, N. \& Ueno, Y. (2008). Are stock repurchases more flexible than dividends? The case of Japanese firms. Applied Financial Economics Letters, 4(5), 315-318.

Baker, H.K., Powell, G.E. \& Veit, E.T. (2003). Why companies use open-market repurchases: A managerial perspective. The Quarterly Review of Economics and Finance, 43(3), 483-504.

Ball, R. \& Brown, P. (1968). An empirical evaluation of accounting numbers. Journal of Accounting Research, 6(2), 159-178.

Barclay, M.J. \& Smith C.W. (1988). Corporate payout policy: Cash dividends verses open market repurchases. Journal of Financial Economics, 22(1), 61-82.

Bartov, E., Krinsky, I. \& Lee, J. (1998). Evidence on how companies choose between dividends and open-market stock repurchases. Journal of Applied Corporate Finance, 11(1), 89-96.

Benartzi, S., Michaely, R. \& Thaler, R. (1997). Do change in dividends signal the future or the past?. The Journal of Finance, 52(3), 1007-1034.

Bhattacharya, S. (1979). Imperfect information, dividend policy, and the "bird in the hand" fallacy. Bell Journal of Economics, 10(1), 259-70.

Black, F. (1976). The dividend puzzle. Journal of Portfolio Management, 2(2), 5-8.

Bowman, R.G. (1983). Understanding and conducting event studies. Journal of Business Finance and Accounting, 10(4), 561-584.

Brav, A., Graham, J.R., Harvey, C.R. \& Michaely, R. (2005). Payout policy in the 21 st century, Journal of Financial Economics, 77(3), 483-527.

Brennan, M. \& Thakor, A. (1990). Shareholder preferences and dividend policy. Journal of Finance, 45(4), 993-1018.

Brown, S.J. \& Warner, J.B. (1985). Using daily stock returns. The case of event studies. Journal of Financial Economics, 14(1), 3-31.

Cesari, A.D., Espenlaub, S. \& Khurshed, A. (2011). Stock repurchases and treasury share sales: Do they stabilize price and enhance liquidity? Journal of Corporate Finance, 17(5), 1558-1579.

Chhachhi, I.S. \& Davidson, W.N. (1997). A comparison of the market reaction to specially designated dividends and tender offer stock repurchases. Financial Management, 26(3), 89-96.

Choi, D. \& Chen, S. (1997). The differential information conveyed by share repurchase tender offers and dividend increases. Journal of Financial Research, 20(4), 529-543.

Chowdhry, B. \& Nanda, V. (1994). Repurchase premia as a reason for dividends: A dynamic model of corporate payout policies, The Review of Financial Studies, 7(2), 321-350.

Comment, R. \& Jarrell, G.A. (1991). The relative signaling power of dutch-auction and fixed-price self-tender offers and open-market share repurchases. The Journal of Finance, 46(4), 1243-1271

Coulton, J.J. \& Ruddock, C. (2011). Corporate payout policy in Australia and a test of the life-cycle theory. Accounting and Finance, 51(2), 381-407.

DeAngelo, H. \& DeAngelo, L. (2006). The irrelevance of the MM dividend irrelevance theorem. Journal of Financial Economics, 79(2), 293-315. 
Deangelo, H., Deangelo, L. \& Skinner, D.J. (1996). Reversal of fortune. Dividend signaling and the disappearance of sustained earnings growth. Journal of Financial Economics, 40(3), 341-371.

Denis, D.J. (1990). Defensive Changes in corporate payout policy: Share repurchases and special dividends. The Journal of Finance, 45(5), 1433-1456.

Dittmar, A.K. \& Dittmar, R.F. (2002). Stock repurchase waves: an explanation of the trends in aggregate corporate payout policy. http://ssrn.com/abstract $=346548$.

Dixon, R. Palmer, G., Stradling, B. \& Woodhead, A. (2008). An empirical survey of the motivation for share repurchases in the UK. Managerial Finance, 34(12), 886-906.

Douglas, A.V. (2007). Managerial opportunism and proportional corporate payout policies. Managerial Finance, 33(1), 26-42.

Dua, V., Puri, H. \& Mittal, R.K. (2010). Impact of buy-back of shares on stock prices in India: An empirical testing of stock market efficiency in its semi-strong form. Pranjana, 13(1), 59-71.

Eije, H.V. \& Megginson, W.L. (2008). Dividends and share repurchases in the European Union. Journal of Financial Economics, 89(2), 347-374.

Fama, E.F. \& Kenneth, R.F.(2001). Disappearing dividends: changing firm characteristics or lower propensity to pay. Journal of Financial Economics, 60(1), 3-43.

Fama, E., Fisher, L., Jensen, M. \& Roll, R. (1969). The adjustment of stock Prices to new information. International Economic Review, 10(1), 1-21.

Fracassi, C. (2008). Stock price sensitivity to dividend changes. Working Paper, 1-39.

Gaspar, J.M., Massa, M., Matos, P., Patgiri R. \& Rehman, Z. (2012). Payout policy choices and shareholder investment horizons, Review of Finance, 17(1), 261-320.

Grullon, G. \& Ikenberry, D.L.(2000). What do we know about stock repurchase. Journal of Applied Corporate Finance, 13(1), 31-51.

Grullon, G. \& Michaely, R. (2002). Dividends, share repurchases and the substitution hypothesis. Journal of Finance, 57(4), 1649-1684.

Grullon, G., Paye, B., Underwood, S., \& Weston, J.P. (2011). Has the propensity to pay out declined? Journal of Financial and Quantitative Analysis, 46 (1), 1-24.

Guay, W. \& Harford, J. (2000). The cash-flow permanence and information content of dividend

increases vs. repurchases. Journal of Financial Economics, 57(3), 385-415.

Gurgul, H. \& Majdosz, P. (2005). Effect of dividend and repurchase announcements on the polish stock market. Operations Research and Decisions, 1(1), 25-41

Hausch, D.B. \& Seward, J. K. (1993). Signaling with dividends and share repurchases: A choice between deterministic and stochastic cash disbursements. The Review of Financial Studies, 6(1), $121-154$

Haw, I.M., Simon, S.S. M., Hu, B. \& Zhang, X. (2011). The contribution of stock repurchases to the value of the firm and cash holdings around the world. Journal of Corporate Finance, 17(1), 152166.

Hsieh, J. \& Wang, Q. (2008). Insiders' tax preferences and firms' choices between dividends and share repurchases. Journal of Financial and Quantitative Analysis, 43(1), 213-244.

Jain, R. (2007). Institutional and individual investor preferences for dividends and share repurchases. Journal of Economics and Business, 59(5), 406-429.

Jain, B. A., Shekhar, C. \& Torbey, V. (2009). Payout initiation by IPO firms: The choice between dividends and share repurchases. The Quarterly Review of Economics and Finance, 49(4), 1275-1297.

Jagannathan, M., Stephens, C. P. \& Weisbach, M. S. (2000). Financial flexibility and the choice between dividends and stock repurchases. Journal of Financial Economics, 57(3), 355-384.

John, K. \& Williams J. (1985). Dividends, dilution and taxes: A signaling equilibrium. Journal of Finance, 40(4), 1053-1070.

Jong, D. A., Dijk, R.V. \& Veld, C. (2003). The dividend and share repurchase policies of Canadian firms: Empirical evidence based on a new research design, International Review of Financial Analysis 12(1), 349-377.

Kadioglu, E. (2008). The Announcement effect of cash dividend: evidence from Turkish capital market. Dissertation, 1-53. 
Koch, A.S. \& Sun, A.X. (2004). Dividend changes and the persistence of past earnings changes. The Journal of Finance, 59(5), 2093-2116.

Kooli, M. \& L'Her, J.F. (2010). Dividends versus share repurchases evidence from Canada: 19852003. The Financial Review, 45(1), 57-81.

Kong, F.L. \& Huang, S. (2014). The persistence of long-run abnormal returns following stock repurchases and offerings. Available at: http://www.mysmu.edu/faculty/fjfu/MgtSci2014.pdf.

Lee B. S. \& Rui, O. M. (2007). Time-series behavior of share repurchases and dividends. The Journal of Financial and Quantitative Analysis, 42(1), 119-142.

Liang, W., Chan, K., Lai, W.H. \& Wang, Y. (2011). Motivation for repurchases: A life cycle explanation. Journal of Financial Services Research, 43(2), 221-242.

Li, K. \& McNally, W. (2003). The decision to repurchase, announcement returns and insider holdings: A conditional event study, The ICFAI Journal of Applied Finance, 9(6), 55-70.

Lie, E. (2000). Excess funds and agency problems: An empirical study of incremental cash disbursements. Review of Financial Studies, 13(1), 219-248.

Lie, E. (2005). Financial flexibility, performance, and the corporate payout choice. The Journal of Business, 78(6), 2179-2202.

Liljeblom, E. \& Pasternack, D. (2006). Share repurchases, dividends and executive options: The effect of dividend protection. European Financial Management, 12(1), 7-28.

McNally, W.J. (1999). Open market stocks repurchase signaling. Financial Management, 28(2), 55- 67.

McWilliams, A. \& Siegel, D. (1997). Event Studies in management research: Theoretical and empirical issues. The Academy of Management Journal, 40(3), 626-657.

Medury, P.V., Bowyer, L.E. \& Srinivasan, V. (1992). Stock Repurchases: A multivariate analysis of repurchasing firms. Quarterly Journal of Business and Economics, 31(1), 21-44.

Miller, M. \& Rock, K. (1985). Dividend policy under asymmetric information. Journal of Finance, 40(4), 1033-1052.

Ming, W.C., Kao, E.H. \& Fung, H. G. (2008). Impact of dividend-protected employee stock options on payout policies: Evidence from Taiwan. Pacific Economic Review, 13(4), 431-452.

Mishra, A.K. (2005). An empirical analysis of share buybacks in India. The ICFAI Journal of Applied Finance, 11(5), 5-24.

Nippel, P. \& Nekat, K. (2009). The impact of a firm's payout policy on stock prices and_shareholders' wealth in an inefficient market. Banking and Finance Review, 1(1), 63-83.

Ofer, A. \& Thakor, A. (1987). A theory of stock price responses to alternative cash disbursementMethods: Stock repurchases and Dividends. Journal of Finance, 42(2), 365-394.

Renneboog, L. \& Trojanowski, G. (2011). Patterns in payout policy and payout channel choice. Journal of Banking and Finance, 35(6), 1477-1490.

Rimbey, J.N. \& Officer, D.T. (1992). Market response to subsequent dividend actions of dividendinitiating and dividend-omitting firms. Quarterly Journal of Business and Economics, 31(1), 3-20.

Sedzro, K. (2009). Comparing the market responses to dividends and repurchases: An empirical study. Journal of Academy of Business and Economics, 9(1), 20-21.

Sedzro, K. (2010). A unifying approach for comparing onetime payouts and recurring dividends. Global Journal of Business Research, 4(2), 141-153.

Skinner, D.J. (2008). The evolving relationship between earnings, dividends, and stock repurchases, Journal of Financial Economics, 87, 582-609.

Thirumalvalavan, P. \& Sunitha, K. (2006). Share price behavior around buyback and dividend announcements in India. Retrieved from http://ssrn.com/abstract=873986.

Wann, C., Long, D.M., Pearson, D., \& Wann, G. (2008). Liquidity shock induced dividend change: market reaction by firm quality. Journal of Academy of Business and Economics, 8(4), 137-151.

Wansley, J.W., Lane, W.R. \& Sarkar, S. (1989). Managements' view on share repurchase and tender offer premiums. Financial Management, 18(3), 97-110.

Weigand, R.A. \& Baker, H.K. (2009). Changing perspectives on distribution policy: The evolution from dividends to share repurchase. Managerial Finance, 35(6), 479- 492. 